\title{
MENINGKATKAN AKTIVITAS DAN PRESTASI BELAJAR MATEMATIKA MATERI BANGUN RUANG SISI LENGKUNG MELALUI PENERAPAN MODEL PEMBELAJARAN KOOPERATIF TIPE STAD PADA SISWA KELAS IX SMP LPMD SUKA MAJU RAMBAH
}

\author{
Nurbaiti \\ SMP LPMD Suka Maju, Rambah \\ nurbaitinur999@gmail.com
}

\begin{abstract}
The purpose of this study was to describe the change in learning attitudes of students IX SMP LPMD Suka Maju Rambah in the 2017/2018 academic year regarding the increase in mathematics learning activities on curved side space building materials after learning through the application of the STAD cooperative learning model. The type of research used is a classroom action research, with a design used in two cycles. The population in this study were students of class IX SMP LPMD Suka Maju Rambah. Each cycle includes planning, action, observation, and reflection. The first cycle's learning outcomes showed that 26 students who completed learning whose score reached $\geq 75$ were 26 students, or the percentage reached $78.78 \%$. In the results of reflection in cycle l, it was found that the active involvement of students was 12 students, or the percentage was only $36.36 \%$. Learning outcomes in cycle II, there was an increase in the number of students who completed, namely as many as 31 students or 93.93\%, with 15.15\%. Meanwhile, students' activeness in the second cycle also increased to 23 students, or $69.69 \%$, with an increase of $33.33 \%$. So it can be concluded that the application of the STAD learning model can improve activities and mathematics learning outcomes of students in grade IX at SMP LPMD Suka Maju, Rambah.
\end{abstract}

Keywords: Learning Activities, Mathematics Learning Outcomes, Action Research, Cooperative STAD.

\begin{abstract}
ABSTRAK Tujuan penelitian ini adalah untuk mendeskripsikan perubahan sikap belajar siswa IX SMP LPMD Suka Maju Rambah Tahun Pembelajaran 2017/2018 tentang peningkatan aktivitas belajar matematika materi bangun ruang sisi lengkung setelah dilakukan pembelajaran melalui penerapan model pembelajaran kooperatif STAD. Jenis penelitian tindakan kelas, dengan rancangan yang digunakan dua siklus. Populasi dalam penelitian ini adalah siswa kelas IX SMP LPMD Suka Maju Rambah. Masing-masing siklus meliputi: perencanaan, tindakan, pengamatan dan refleksi. Hasil belajar pada siklus I, menunjukkan bahwa siswa yang tuntas dalam pembelajaran yang nilainya mencapai $\geq 75$ sebanyak 26 siswa atau prosentasenya mencapai $78,78 \%$. Hasil refleksi diklus I, diperoleh bahwa keterlibatan siswa secara aktif sebanyak 12 siswa, atau persentasenya hanya 36,36\%. Hasil belajar pada siklus II, terdapat peningkatan jumlah siswa yang tuntas, yaitu sebanyak 31 siswa atau 93,93\%, dengan kenaikan sebesar 15,15\%. Sedangkan untuk keaktifan siswa pada siklus II juga mengalami peningkatan menjadi 23 siswa, atau 69,69\%, dengan peningkatan sebesar 33,33\%. Sehingga, dapat disimpulkan bahwa penerapan model pembelajaran STAD dapat meningkatkan aktivitas dan hasil belajar matematika siswa kelas IX SMP LPMD Suka Maju, Rambah.
\end{abstract}

Kata-kata Kunci : Aktivitas Belajar, Prestasi Belajar Matematika, Penelitian Tindakan Kelas, Kooperatif Tipe STAD 


\section{PENDAHULUAN}

Pencapaian hasil belajar secara maksimal adalah tujuan pokok seorang guru dalam pelaksanaan kegiatan belajar mengajar di kelas. Dedikasi, loyalitas dan kwalitas profesinya senantiasa dicurahkan untuk kepentingan anak didiknya agar mencapai hasil belajar secara maksimal. Untuk mencapai hasil itu, seorang guru dituntut untuk mencari bentuk pembelajaran yang efektif, menarik dan menyenangkan. Berbagai model pembelajaran yang ada perlu dipilih dan disesuaikan dengan materi saat itu. Disamping penerapan suatu bentuk model pembelajaran, guru perlu mengupayakan dan mengembangkan kemapuan siswa untuk menemukan sendiri, mampu menilai dirinya sendiri dengan tujuan siswa dapat membangun pemahaman dan pengetahuanya.

Ketergantungan siswa kepada guru yang notabene sebagai perantara suatu ilmu, hendaklah dikurangi dan sebaliknya dikembangkan pola kegiatan pembelajaran mandiri, menemukan jawaban sendiri dalam pemecahan suatu kasus, dan guru hanya sebagai fasilitator melaui pembimbingan pada kelompok kerja diskusi. Pembentukan kelompok diskusi yang dibuat hendaknya dapat merata secara kualitatif, artinya paling tidak ada satu siswa yang mampu menjadi koordinator untuk memimpin teman-temanya dalam kerja kelompok, dan akhirnya dapat tercapai tujuan kegiatan belajar mengajar saat itu.

Pembelajaran yang dilaksanakan saat ini masih perlu dilakukan perbaikan dalam pelaksanaannya, sehingga, dengan adanya proses pembelajaran yang baik juga akan meningkatkan prestasi belajar siswa pula. Pada proses pembelajaran, dapat digunakan model pembelajaran yang mengaktifkan siswa untuk kerja dalam satu kelompok, memecahkan soal dan menemukan sendiri suatu pemahaman konsep tertentu dengan bimbingan guru, akan membawa situasi belajar siswa ke dunianya sendiri, dunia bermain yang penuh dengan keasyikan belajar, tanpa tekanan atau paksaaan terhadap siswa. Dengan demikian pembelajaran yang disajikan akan lebih efektif, aktif dan menyenangkan.

Salah satu model pembelajaran yang dapat digunakan adalah Pembelajaran Kooperatif tipe STAD. Model Pembelajaran kooperatif tipe STAD merupakan pendekatan pembelajaran yang menekankan pada aktivitas dan interaksi di antara siswa untuk saling memotivasi dan saling membantu dalam menguasai materi pelajaran guna mencapai prestasi yang maksimal (Wijaya \& Arismunandar, 2018). Herdian (Esminarto, Sukowati, Suryowati, \& Anam, 2016) menyatakan bahwa model pembelajaran STAD mempunyai beberapa keunggulan, antara lain sebagai berikut: semua anggota kelompok wajib mendapat tugas, ada interaksi langsung antar siswa dengan siswa dan siswa dengan guru, siswa dilatih untuk mengembangkan keterampilan sosial, mendorong siswa untuk menghargai pendapat orang lain, dapat meningkatkan kemampuan akademik siswa dan melatih siswa untuk berani bicara di depan kelas.

Model pembelajaran kooperatif memiliki enam langkah dalam pembelajaran kooperatif yaitu: Fase Pertama, menyampaikan tujuan dan memotivasi siswa. Guru 
menyampaikan semua tujuan pelajaran yang ingin dicapai pada pelajaran tersebut dan memotivasi siswa belajar. Fase kedua, menyampaikan informasi. Guru menyampaikan informasi kepada siswa dengan jalan mendemonstrasikan atau lewat bahan bacaan. Fase ketiga, mengorganisasikan siswa ke dalam kelompokkelompok belajar. Guru menjelaskan kepada siswa bagaimana caranya membentuk kelompok belajar dan membantu setiap kelompok agar melakukan transisi secara efisien. Fase keempat, membimbing kelompok bekerja dan belajar. Guru membimbing kelompok-kelompok belajar pada saat mereka mengerjakan tugas. Fase kelima adalah evaluasi. Guru melakukan evaluasi dengan menggunakan strategi evaluasi yang konsisten dengan tujuan pembelajaran. Fase keenam, memberikan penghargaan. Guru mempersiapkan struktur reward yang akan diberikan kepada siswa. Guru mencari cara-cara untuk menghargai upaya atau hasil belajar individu maupun kelompok (Ismail dalam Wijaya \& Arismunandar, 2018).

Belajar dimaknai sebagai proses perubahan perilaku sebagai hasil interaksi individu dengan lingkungannya. Perubahan perilaku terhadap hasil belajar bersifat kontiniu, fungsional, positif, aktif, dan terarah. Proses perubahan tingkah laku dapat terjadi dalam berbagai kondisi berdasarkan penjelasan dari para ahli pendidikan dan psikologi (Pane, 2017). Sedangkan Prestasi berasal dari bahasa Belanda yakni Prestatie yang berarti hasil usaha. Prestasi belajar atau hasil belajar dapat diwujutkan dalam tiga aspek tujuan pendidikan yang akan dicapai. Ketiga aspek itu yakni aspek kognitif (penguasaan kognitif), aspek afektif (berhubungan dengan sikap dan nilai), aspek psikomotor (kemampuan). Ketiganya tidak berdiri sendiri, tetapi merupakan satu kesatuan yang tidak terpisahkan (Sudjana, 1992).

Belajar memerlukan aktivitas, seperti yang dikemukakan oleh Hamalik (Ayuwanti, 2017) menyatakan bahwa pengajaran yang efektif adalah pengajaran yang menyediakan kesempatan belajar sendiri atau melakukan aktivitas sendiri. Senada dengan hal tersebut, Winkel (Ayuwanti, 2017) mengatakan bahwa belajar adalah suatu aktivitas mental/ psikis yang berlangsung dalam interaksi aktif dengan lingkungan, yang menghasilkan perubahan-perubahan dalam pengetahuan pemahaman, keterampilan, dan nilai sikap. Aktivitas belajar memiliki peranan penting pada proses pembelajaran, bila berlangsung dengan baik, akan berpotensi memberikan hasil atau prestasi belajar yang baik pula bagi siswa.

Menurut Hudojo, prestasi belajar matematika merupakan tampilan pemahaman dan penguasaan terhadap materi matematika yang telah dipelajari siswa (Isharyadi, 2017). Sedangkan menurut (Sirait, 2016) prestasi belajar matematika merupakan salah satu ukuran tingkat keberhasilan siswa setelah menjalani proses belajar matematika. Penilaian hasil belajar, termasuk mata pelajaran matematika oleh guru terdiri atas ulangan harian, ulangan tengah semester, ulangan akhir semester dan ulangan kenaikan kelas. Ulangan harian merupakan kegiatan yang dilakukan oleh guru secara periodik untuk menilai atau mengukur pencapaian kompetensi setelah menyelesaikan satu kompetensi dasar atau lebih (Depdiknas, 2007). 
Berdasarkan paparan tersebut, penelitian tindakan ini dilakukan dengan tujuan untuk meningkatkan aktivitas dan prestasi belajar matematika siswa kelas IX SMP LPMD SUka Maju Rambah Tahun Pembelajaran 2017/ 2018 materi bangun ruang sisi lengkung setelah dilakukan pembelajaran melalui penerapan model pembelajaran kooperatif STAD.

\section{METODE PENELITIAN}

Penelitian yang peneliti lakukan adalah menggunakan rancangan penelitian tindakan yang dilaksanakan di kelas, sehingga disebut Penelitian Tindakan Kelas (PTK). Penelitian ini terdiri dari 2 siklus masing-masing siklus meliputi : perencanaan, tindakan, pengamatan dan refleksi (Arikunto, Suhardjono, \& Supardi, 2006).

Penelitian ini dilaksanakan dalam 2 siklus dengan masing masing siklus terdiri atas dua kali tatap muka. Siklus I membahas materi menentukan luas sisi permukaan bangun ruang sisi lengkung, dan siklus II membahas materi menentukan volume bangun ruang sisi lengkung.

Adapun rincian kegiatan PTK yang dilaksanakan sesuai dengan pendapat Kunandar (dalam Suprapti, 2019) yaitu:

1. Perencanaan

Pada tahap perencanaan ini guru menyusun RPP, Lembar Kerja Siswa (LKS), lembar observasi, serta soal untuk melihat pemahaman siswa terhadap materi yang diajarkan.

2. Tindakan

Pada tahap pelaksanaan, guru mengajar sesuai dengan RPP. Pada saat pembelajaran berlangsung, observer mengamati jalannya proses pembelajaran.

3. Pengamatan

Observasi dilakukan selama pengamatan tindakan sebagai upaya mengetahui jalannya pembelajaran. Kegiatan pada tahap ini juga merupakan kegiatan pengumpulan data. Pengumpulan data dilakukan dengan format observasi yang telah disusun.

4. Refleksi

Pada tahap ini guru berdiskusi dengan observer tentang pembelajaran yang telah dilakukan, baik kekurangan maupun ketercapaian pembelajaran. Hal ini digunakan untuk menyimpulkan data atau informasi yang dikumpulkan sebagai pertimbangan perencanaan pembelajaran pada siklus berikutnya.

Subyek penelitian ini adalah siswa kelas IX SMP LPMD Suka Maju Rambah Tahun Pembelajaran 2017/2018. Dipilihnya kelas tersebut karena oleh peneliti dianggap memenuhi syarat untuk dijadikan subyek penelitian pembelajaran dengan model pembelajaran kooperatif STAD. Setting penelitian ini dilakUkan pada kelas IX SMP LPMD Suka Maju Rambah Tahun Pembelajaran 2017/2018 pada semester ganjil dengan program tahunan, dan program semester yang direncanakan oleh peneliti selaku guru mata pelajaran matematika. Siklus pelaksanaan penelitian tindakan dapat dilihat pada gambar bagan berikut. 


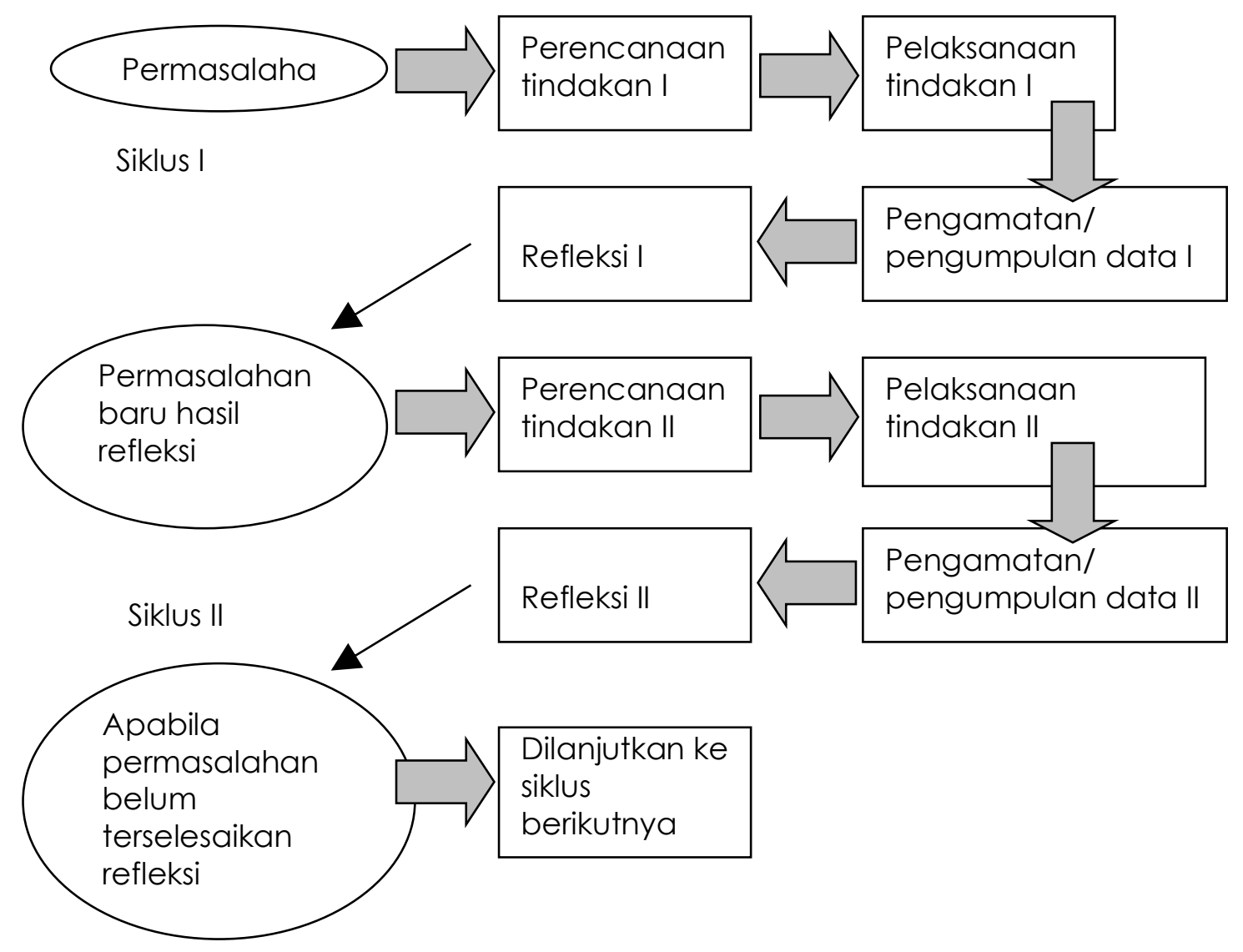

Gambar 1. Siklus PTK

Peneliti membuat instrumen penilaian kognitif dengan menetapkan kriteria ketuntasan minimal (KKM) yang harus dicapai untuk setiap peserta didik yaitu 75. Indikator keberhasilan penelitian ini dengan cara menentukan rata-rata nilai hasil belajar siswa. Jika rata-rata hasil belajar di awal dan diakhir tindakan mengalami peningkatan $10 \%$, dan secara klasikal $85 \%$ dari jumlah siswa telah memperoleh nilai di atas KKM maka penelitian dikatakan berhasil. Peneliti juga membuat instrumen penilaian afektif dengan menetapkan 5 butir indikator penilaian minat, dengan rentang nilai $1-4$, untuk mengetahui keterlibatan siswa secara aktif dalam pembelajaran.

- Skor terendah seorang siswa $=1 \times 5=5$

- Skor tertinggi seorang siswa $=4 \times 5=20$

Hasil skor siswa dijumlah dan bisa dirumuskan dalam salah satu kategori :

* 5-8 : tidak aktif

* 9-12 : kurang aktif

* 13-16: aktif

* $17-20$ : sangat aktif

Penelitian tindakan ini berhasil jika keterlibatan siswa secara aktif pada pembelajaran dari siklus I ke siklus II jumlahnya semakin lama semakin meningkat. Siswa dinyatakan telah mengikuti pembelajaran secara aktif jika nilai hasil observasi mencapai $\geq 13$. 
Peneliti membuat angket dengan menetapkan 10 butir indikator dengan rentang skor $1-4$.

- Skor terendah seorang siswa $=1 \times 10=10$

- Skor tertinggi seorang siswa $=4 \times 10=40$

Hasil skor siswa dijumlah dan bisa dirumuskan dalam salah satu kategori :

* $10-18$ : tidak menyenangkan

* 19-25 : kurang menyenangkan

* 26-33 : menyenangkan

* $34-40$ : sangat menyenangkan

Penelitian tindakan ini berhasil jika respons siswa terhadap pembelajaran kooperatif tipe STAD dari siklus I ke siklus II semakin lama semakin banyak siswa yng menyenangi. Siswa dinyatakan meningkat responnya terhadap pembelajaran dengan model kooperatif tipe STAD jika hasil angketnya mencapai $\geq 26$.

\section{HASIL DAN PEMBAHASAN}

\section{Hasil Penelitian Siklus I}

Dari hasil pemeriksaan tes yang dilakukan oleh peneliti sebelum dilakukan pembelajaran kooperatif tipe STAD diperoleh gambaran ada 15 siswa dari 33 siswa $(45,45 \%)$ telah tuntas dalam memahami materi dalam pembelajaran dengan ratarata hasil test yang telah dicapai 61,11. Setelah dilakukan tindakan pada siklus I, di akhir siklus diberikan tes, dan diperoleh hasil bahwa siswa yang mencapai KKM meningkat menjadi 26 siswa dari 33 siswa, atau 78,78\% dengan rata-rata yang diperoleh adalah 73,03.

Untuk aktivitas siswa, dari hasil pengamatan yang peneliti lakukan beserta observer terhadap aktivitas siswa dalam pembelajaran, tampak pada tabel berikut.

Tabel 1. Keterlibatan Siswa dalam Pembelajaran

\begin{tabular}{cccc}
\hline No. & Bentuk Keterlibatan Siswa & Frekuensi & Presentase \\
\hline 1 & Tidak Aktif & 10 & $30,3 \%$ \\
\hline 2 & Kurang Aktif & 11 & $33,3 \%$ \\
\hline 3 & Aktif & 9 & $27,3 \%$ \\
\hline 4 & Sangat Aktif & 3 & $9,1 \%$ \\
\hline
\end{tabular}

Pembelajaran kooperatif tipe STAD yang dilakukan pada siklus I membuat 12 siswa aktif dan terlibat dalam pembelajaran dengan persentasi sebesar 36,36\%.

Untuk respon siswa terhadap proses pembelajaran dengan menggunakan model pembelajaran kooperatif tipe STAD, diberikan angket kepada siswa pada akhir pertemuan di siklus I. Hasilnya diperoleh bahwa menurut 13 siswa, pembelajaran menggunakan model kooperatif tipe STAD menyenangkan. Jumlah siswa ini memiliki persentase sebesar 39,39\%. Hasil respon siswa tersebut dapat dilihat pada tabel berikut. 
Tabel 2. Respon siswa terhadap pembelajaran kooperatif tipe STAD

\begin{tabular}{cccc}
\hline No. & Respon Siswa & Frekuensi & Presentase \\
\hline 1 & Tidak Menyenangkan & 9 & $27,3 \%$ \\
\hline 2 & Kurang Menyenangkan & 11 & $33,3 \%$ \\
\hline 3 & Menyenangkan & 9 & $27,3 \%$ \\
\hline 4 & Sangat Menyenangkan & 4 & $12,1 \%$ \\
\hline
\end{tabular}

Pada pelaksanaan pembelajaran, terdapat hal-hal yang ditemukan, yang perlu diperbaiki untuk pelaksanaan siklus II beserta alternatif pemecahan masalah yang dilakukan, yaitu:

1. Pada umumnya siswa masih kurang hati-hati atau kurang teliti dalam menyelesaikan masalah yang berkaitan dengan menentukan luas sisi bangun ruang sisi lengkung, sehingga perlu menjelaskan kembali rumus untuk menentukan luas sisi bangun ruang sisi lengkung dan penggunaanya dalam pemecahan masalah.

2. Sebagian siswa termotivasi untuk aktif dan kreatif di dalam menyelesaikan permasalahan yang muncul di lembar kerja siswa, namun sebagian siswa lagi masih kurang aktif dalam pembelajaran. Sehingga perlu memberikan motivasi kembali kepada siswa yang kurang aktif dalam pembelajaran dengan jalan mendekati siswa tersebut dan menumbuhkan semangat belajar mereka agar bisa aktif dalam pembelajaran.

3. Hasil dari kerja kelompok yang dilakukan siswa masih ada yang melenceng dari masalah yang ada. Sehingga perlu dilakukan diskusi kembali dengan anggota kelompoknya, namun jika masih salah, maka guru yang akan meluruskan jawaban yang salah tersebut.

4. Siswa masih kurang keberanian dan kurang percaya diri untuk mempresentasikan hasil kerjanya ke depan. Sehingga, guru perlu memotivasi siswa untuk mengungkapkan pendapatnya di depan dengan berani dan percaya diri karena hal tersebut sangat diperlukan untuk siswa di masa yang akan datang, apabila ada kegagalan, guru akan memberikan bimbingan seperlunya untuk kesempurnaan pendapat itu.

5. Penguasaan materi prasyarat siswa kurang, sehingga kegiatan diskusi tidak berjalan maksimal. Langkah yang dilakukan adalah mengulang kembali pengetahuan prasyarat yang mendukung topik yang diberikan dengan tanya jawab.

\section{Hasil Penelitian Siklus II}

Setelah dilakukan refleksi pada akhir siklus I dan sebelum dimulainya siklus II, dilakukan perbaikan proses pembelajaran. Selanjutnya, pada akhir siklus II diberikan tes hasil belajar, dan dari hasil pemeriksaan tes yang dilakukan oleh peneliti diperoleh bahwa terdapat 31 siswa dari 33 siswa (93,93\%) telah tuntas dalam memahami materi pada pembelajaran pada siklus II dengan rata-rata hasil tes yang telah dicapai 83,63\%. Hasil ini menunjukkan bahwa terdapat peningkatan siswa yang tuntas yaitu 5 siswa 
dari siklus I atau meningkat sebesar 15,15\%. Sementara dari keaktifan siswa, pada akhir siklus II ini, diperoleh bahwa siswa yang terlibat aktif dalam pembelajaran sebanyak 23 siswa atau sekitar 69,69\%. Hasil ini juga menunjukkan bahwa pembelajaran yang dilakukan telah meningkatkan siswa aktif sebanyak 11 siswa atau meningkat 33,33\% dari siklus I.

Untuk respon terhadap proses pembelajaran menggunakan model kooperatif tipe STAD, dari hasil pemeriksaan angket pada akhir siklus II dapat dilihat pada tabel berikut:

Tabel 3. Respon siswa terhadap pembelajaran kooperatif tipe STAD

\begin{tabular}{cccc}
\hline No. & Respon Siswa & Frekuensi & Presentase \\
\hline 1 & Tidak Menyenangkan & 3 & $9,1 \%$ \\
\hline 2 & Kurang Menyenangkan & 3 & $9,1 \%$ \\
\hline 3 & Menyenangkan & 14 & $42,4 \%$ \\
\hline 4 & Sangat Menyenangkan & 13 & $39,4 \%$ \\
\hline
\end{tabular}

Berdasarkan tabel tersebut, terlihat bahwa siswa semakin menyenangi proses pembelajaran menggunakan kooperatif tipe STAD, dengan respon menyenangkan dan sangat menyenangkan sebanyak 27 siswa atau $81,81 \%$. Hasil ini menunjukkan adanya peningkatan respon siswa tersebut sebesar 14 siswa atau $42,42 \%$ dari siklus I.

Pada pelaksanaan pembelajaran pada siklus II, terdapat hal-hal yang ditemukan, yaitu:

1. Dalam menghitung dan menyelesaikan soal yang berkaitan dengan volume bangun ruang sisi lengkung sudah banyak siswa yang mampu dengan baik dan melakukan langkah yang benar berdasar pada LKS yang diberikan oleh guru. Namun, dapat dilakukan penjelasan kembali dan menambah latihan kepada siswa yang masih kesulitan untuk menemukan sendiri rumus volume bangun ruang sisi lengkung.

2. Siswa antusias sekali dalam kegiatan pembelajaran dengan kelompoknya untuk menemukan penyelesaian dari permasalahan yang muncul dalam Lembar Kerja, meskipun ada beberapa siswa yang tidak mengikuti kerja kelompok (pembelajaran) secara aktif. Untuk menyelesaikannya, dilakukan dengan cara mendekati siswa tersebut dan memotivasi betapa pentingnya menjadi siswa yang mengerti dengan baik pelajaran yang dipelajari.

3. Waktu pelaksanaan kegiatan penelitian tindakan kelas tidak sesuai dengan waktu yang telah direncanakan. Hal ini disebabkan materi yang dipelajari menitikberatkan pada kerja. Selain itu, pelaksanaan juga bersamaan dengan kegiatan UN bagi kelas IX, sehingga membuat konsentrasi siswa terpecah. 


\section{KESIMPULAN}

Berdasarkan hasil penelitian tindakan kelas yang telah peneliti laksanakan di SMP LPMD Suka Maju Rambah tahun pelajaran 2017/2018 ditemukan bahwa hasil belajar matematika secara individual siswa kelas IX masih rendah yaitu $45,45 \%$ siswa yang hasil belajarnya memperoleh nilai $\geq 75$ sesuai dengan KKM yang ditetapkan. Untuk meningkatkan hasil belajar matematika siswa, tindakan yang dilakukan adalah dengan menerapkan model pembelajaran kooperatif tipe STAD.

Setelah penelitian tindakan kelas pada siswa kelas IX SMP LPMD Suka Maju Rambah yang berlangsung selama dua siklus, diperoleh beberapa kesimpulan sebagai berikut:

1. Ada peningkatan prestasi belajar siswa yang dari hasil tes materi luas dan volume bangun ruang sisi lengkung yaitu dari $15,15 \%$ pada sebelum pelaksanaan tindakan, menjadi 78,78\% pada siklus I dan menjadi 93,93\% pada siklus II.

2. Ada perubahan sikap belajar yang positif dari hasil observasi oleh observer pada materi luas dan volume bangun ruang sisi lengkung setelah dilakukan pembelajaran melalui penerapan model pembelajaran kooperatif STAD dari siklus I sebesar 36,36\% menjadi $69,69 \%$ pada siklus II, atau meningkat sebesar $33,33 \%$

3. Ada perubahan respon belajar yang positif pada materi luas dan volume bangun ruang sisi lengkung setelah dilakukan pembelajaran melalui penerapan model pembelajaran kooperatif STAD dari siklus I sebesar 39,39\% menjadi $81,81 \%$ pada siklus II, atau meningkat sebesar $42,42 \%$.

\section{DAFTAR PUSTAKA}

Arikunto, S., Suhardjono, \& Supardi. (2006). Penelitian Tindakan Kelas. Jakarta: Bumi Aksara.

Ayuwanti, I. (2017). Meningkatkan Aktivitas dan Hasil Belajar Matematika Menggunakan Model Pembelajaran Kooperatif Tipe Group Investigation di SMK Tuma'ninah Yasin Metro. SAP (Susunan Artikel Pendidikan), 1(2), 105-114. https://doi.org/10.30998/sap.v1i2.1017

Depdiknas. Permendiknas No. 20 Tahun 2007 tentang Standar Proses Untuk Satuan Pendidikan Dasar dan Menengah. , (2007).

Esminarto, E., Sukowati, S., Suryowati, N., \& Anam, K. (2016). Implementasi Model Stad Dalam Meningkatkan Hasil Belajar Siwa. Briliant: Jurnal Riset Dan Konseptual, 1 (1), 16. https://doi.org/10.28926/briliant.vli1.2

Isharyadi, R. (2017). Pengaruh Mathematical Beliefs terhadap Prestasi Belajar Matematika Siswa SMA. PYTHAGORAS: Jurnal Program Studi Pendidikan Matematika, 6(1), 1-10. https://doi.org/10.33373/pythagoras.v6il.596

Pane, A. (2017). Belajar dan Pembelajaran Aprida Pane Muhammad Darwis Dasopang. Fitrah, 03 (2), 333-352.

Sirait, E. D. (2016). Pengaruh Minat Belajar Terhadap Prestasi. Jurnal Formatif, 6(1), 3543. 
Sudjana, N. (1992). Penilaian Hasil Proses Belajar Mengajar. Bandung: Remaja Rosdakarya.

Suprapti, S. (2019). Penerapan Model Pembelajaran Think Pair Share Untuk Meningkatkan Hasil Belajar Matematika Siswa Kelas 3 SDN 009 Rambah Samo. Jurnal Absis: Jurnal Pendidikan Matematika Dan Matematika, 2(1), 138-147. https://doi.org/10.30606/absis.v2i1.215

Wijaya, H., \& Arismunandar, A. (2018). Pengembangan Model Pembelajaran Kooperatif Tipe STAD Berbasis Media Sosial. Jurnal Jaffray, 16(2), 175. https://doi.org/10.25278/jj71.v16i2.302 